Relations industrielles

Industrial Relations

\title{
The Role of the State in Industrial Relations: A Comment
}

\section{Bryan M. Downie}

Volume 45, numéro 1, 1990

URI : https://id.erudit.org/iderudit/050567ar

DOI : https://doi.org/10.7202/050567ar

Aller au sommaire du numéro

\section{Éditeur(s)}

Département des relations industrielles de l'Université Laval

\section{ISSN}

0034-379X (imprimé)

1703-8138 (numérique)

Découvrir la revue

\section{Citer cet article}

Downie, B. M. (1990). The Role of the State in Industrial Relations: A Comment. Relations industrielles / Industrial Relations, 45(1), 169-186.

https://doi.org/10.7202/050567ar
Résumé de l'article

In this paper, the author takes issues with comments by Sack and Lee that changes to British Columbia's labour legislation represent retrenchment in Canadian public policy in labour relations. In discussing the issue, he draws on the experience with a similar approach in Ontario.
Tous droits réservés @ Département des relations industrielles de l'Université Laval, 1990
Ce document est protégé par la loi sur le droit d'auteur. L'utilisation des services d'Érudit (y compris la reproduction) est assujettie à sa politique d'utilisation que vous pouvez consulter en ligne.

https://apropos.erudit.org/fr/usagers/politique-dutilisation/ 


\title{
DISCUSSION
}

\section{The Role of the State in Industrial Relations A Comment}

\section{Bryan M. Downie}

\begin{abstract}
In this paper, the author takes issues with comments by Sack and Lee that changes to British Columbia's labour legislation represent retrenchment in Canadian public policy in labour relations. In discussing the issue, he draws on the experience with a similar approach in Ontario.
\end{abstract}

In a recent article in Relations Industrielles, Sack and Lee argue that state intervention has become intrusive in Canadian industrial relations (Sack and Lee, 1989). They allege there have been «broad-based» assaults on collective bargaining by the state and a real danger that the collective bargaining system, in place since World War II, could be dismantled.

They base their assertions on the increase in back-to-work legislation by provincial and federal governments, the use of wage controls in the public sector in a number of jurisdictions, and statutory criteria imposed on interest arbitrators requiring them to take into account government's ability to pay.

As particularly vexatious, however, they point to recent changes to labour legislation in British Columbia.

Clearly, the most extreme example of retrenchment in Canada is supplied by recent labour legislation in British Columbia [...]. Under this legislation which established a permanent framework for what would otherwise be exceptional State intervention, the Cabinet has the power to end strikes and impose binding arbitration when it decides that a major dispute is contrary to the public interest or a threat to the province's economy. This power applies to both the private and public sectors. Furthermore, the B. C. legislation abolishes the province's labour board and gives the commissioner of a newly established industrial relations council sweeping powers to intervene during collective bargaining (p. 204).

Much of what Sack and Lee have to say concerning public policy I agree with and, overall, I do not disagree with their central premise. However, their article does obscure and overlook the positive features of the B.C. legislation.

* Downie, B.M., Professor, School of Industrial Relations and the School of Business, Queen's University. He was Chairman of the Ontario Education Relations Commission from 1979 to 1987.

Relat. ind., vol. 45, no 1, 1990 ㄷ PUL ISSN 0034-379 X 
This is not a treatise intended to defend the B.C. legislation in its entirety or the way it was introduced. Nevertheless, the model chosen for dispute resolution in the collective bargaining process has a great deal of merit and clearly does not represent retrenchment in Canadian public policy as Sack and Lee argue. Indeed, the experience with a similar approach in Ontario suggests that the model chosen in B.C. may meet some of the very concerns about state intervention articulated by them.

This article points out the congruence between the B.C. and Ontario approaches, provides some evidence from the Ontario experience which runs counter to the arguments of Sack and Lee, and gives some specific examples and lessons in dispute resolution from that experience.

\section{DISPUTE RESOLUTION UNDER B.C.'S INDUSTRIAL RELATIONS ACT}

Sack and Lee provide only a cursory view of the B.C. legislation. In light of their sweeping and blanket condemnation of the approach, the changes in dispute resolution procedures to B.C.'s labour legislation (previously known as the Labour Code) are worth reviewing.

The new Industrial Relations Council mentioned by Sack and Lee has both quasi-judicial and facilitative functions. The Council has been given the duties of the province's Labour Relations Board (now known as the Industrial Relations Adjudication Division) and the mediation services branch of the Ministry of Labour (the Disputes Resolution Division «DRD»). This is perhaps the most controversial aspect of the legislation and an aspect on which I will specifically comment at a later point.

Under the statute, the DRD has a duty to monitor all negotiations and to assist the parties in the voluntary resolution of collective bargaining conflict. Both private and public sector employers are required to file their collective agreements with the DRD, advise the DRD when they commence bargaining, when notice to strike or lockout has been given, and when a strike or lockout commences. The Council also must gather and publish data and information on collective bargaining in the province.

None of this is new but the Act also provides for an industrial relations "Commissioner" who oversees the operations of the Council and has a mandate to regulate collective bargaining and disputes arising from it. Sack and Lee charge that this constitutes unwarranted state intervention in the collective bargaining process. However, as will be seen, while the dispute settlement provisions are thorough none of the Commissioner's options are extraordinary or out of the mainstream of industrial relations thought.

When a strike or lockout has commenced, or is threatened, the Commissioner must keep the Minister of Labour informed and may do any one or all of the following: refer the dispute to mediation, appoint a fact finder who may make nonbinding recommendations on terms of settlement, confer with the parties personally and make recommendations to them on how their dispute should be resolved, refer the matter to a public interest inquiry board (PIIB). 
Under the provisions of the statute, a PIIB has a duty to inquire into the dispute and make recommendations on terms of agreement to end the dispute. The Commissioner has the authority to publish the Board's recommendations and also to order a supervised vote of the employees on acceptance or rejection of the Board's recommended terms of settlement. In addition, during a strike or lockout, the Commissioner may order a supervised vote of the employees on the employer's last offer. Then, too, after receiving a report from the Commissioner with respect to an impending or existing strike (or lockout), the Minister of Labour may direct the Industrial Relations Council to designate employees in the bargaining unit as essential and/or may order a 40 day "cooling off» period during which the strike must end.

Finally, if the Legislature is not in session, the Cabinet, under the terms of an amendment enacted but not yet in force, may direct the Commissioner to prohibit or terminate a strike or lockout if there is a threat to the province's economy or if an "essential service» is involved. The Commissioner is empowered to utilize mechanisms such as final-offer arbitration, mediation-arbitration and conventional arbitration to resolve the dispute.

Although the procedures are comprehensive, they in and of themselves are innocuous. The impact of the legislation will very much depend on how it is administered. In this regard the experience in Ontario is informative.

\section{DISPUTE RESOLUTION IN ONTARIO EDUCATION}

A similar concept to the one just described was adopted in Ontario in 1975 when legislation was enacted to regulate and assist collective bargaining in the 270 bargaining units in Ontario education. The legislation - the School Boards and Teachers Collective Negotiations Act or more commonly known as Bill 100 - created a five-person government agency known as the Education Relations Commission (ERC). In many respects, it is modelled along the lines suggested in the Federal task force report of 1968 for a public interest disputes commission (Woods, Carrothers, Crispo and Dion, 1968).

The ERC, in purpose and approach, is not unlike the Industrial Relations Council in British Columbia. For example, the purposes of the Council, as listed in the B.C. legislation, are very similar to the purposes outlined in Bill 100 and the functions of the two agencies as provided in the respective statutes are very similar. The broad provisions of the B.C. statute regarding dispute resolution are consistent with the ideas contained in the above mentioned Task Force report and are not unlike the provisions of Bill 100.

The specific dispute settlement interventions included in the B.C. statute are similar to those that are in Bill 100 and/or are similar to those that, in practice, have been utilized by the Education Relations Commission over the past fourteen years. These will be outlined shortly.

The Ontario legislation has been considered a successful innovation in industrial relations. Since 1975, two reviews of Bill 100 have been conducted and on both occasions no recommendations have been made to change the 
legislative framework. Perhaps most importantly, from the year of its creation to the present, the independence of the Education Relations Commission from Cabinet interference has been rigorously protected and maintained by Commission personnel. In no sense has there been unwarranted state intervention.

\section{EXPERIENCE TO DATE}

It is significant to note that bona fide give-and-take collective bargaining exists in the 270 plus bargaining units in Ontario education. I have reported on this elsewhere but suffice it to say that union and school board sanctions remain very viable options in collective bargaining disputes and third party intervention has been minimized (Downie, 1984; Ontario Education Relations Commission, 1987). A more recent independent assessment includes similar conclusions (Jackson, 1989). There is evidence as well that the unions which negotiate under its provisions have made significant gains since its enactment (Charles and Humphreys, 1985).

For these and other reasons, then, the ERC experience belies the argument by Sack and Lee that such an approach per se constitutes a retrenchment. From this experience the dispute resolution provisions are not a threat to the collective bargaining process. Instead, it can be argued that they are more likely to protect collective bargaining to the degree that the procedures increase public acceptance, and more importantly the politicians' toleration, of collective bargaining sanctions. There are several reasons for so believing.

Sack and Lee are concerned about the increasing use of back-to-work legislation. They cite data which I have included as Table 1. They state:

[...] there has been an increasing incidence of ad hoc interventions by governments in labour disputes in Canada. The table 1 shows a disturbing increase in the number of occasions on which federal and provincial governments have employed emergency back-to-work legislation since 1950 (p. 202).

One reason, of course, is that with the sharp rise in public sector bargaining since the mid-60's governments face intense pressure to intervene and legislate an end to important labour disputes. Most governments regardless of political stripe have difficulty resisting that pressure.

This provides the central raison d'être for an independent disputes resolution commission. The Education Relations Commission has tried to ensure that the parties' sanctions are effective and not immediately ended by legislation.

In this respect, the record speaks for itself. Table 2 lists the number of sanctions, the number of advisements from the ERC, and the number of occasions back-to-work legislation has been enacted since the inception of Bill 100. (The ERC has a duty under the legislation to advise the government when a strike or lockout places in jeopardy the students' courses of study.) 
Table 1

Back-to-Work Legislation, 1950-84

$\begin{array}{cccc}\text { Years } & \text { Federal } & \text { Provincial } & \text { Total } \\ 1950-54 & 1 & - & 1 \\ 1955-59 & 1 & 1 & 2 \\ 1960-64 & 2 & 1 & 3 \\ 1965-69 & 2 & 8 & 10 \\ 1970-74 & 4 & 9 & 13 \\ 1975-79 & 6 & 16 & 22 \\ 1980-84 & 1 & 18 & 19 \\ 1984-88 & 4 & 11 & 15\end{array}$

Source: Canada, Department of Labour, Federal-Provincial Branch (Ottawa).

Over the years there has been a total of 54 strikes. There has been an advisement from the ERC to terminate a sanction, however, on only 8 occasions. Five of these occurred during the first year of the statute. Therefore, since that time there have been only three advisements from the ERC. In two of those cases the Commission worked behind the scenes to facilitate a voluntary resolution of the dispute between the parties before back-to-work legislation was passed. As a consequence, for the past thirteen years there has been only one case where back-to-work legislation has actually been enacted.

The above statistics do not tell the whole story, however. The provision for a dispute settlement agency with broad powers to assist the parties should insulate and protect the collective bargaining process from political interference. Industrial relations specialists (the Chairperson, or Commissioner, and members) are likely to be far knowledgeable about collective bargaining and more permissive and patient with regard to strikes and lockouts than elected officials or career civil servants, particularly if they have at their disposal a large arsenal of dispute resolution procedures. Indeed, the experience in Ontario does indicate that such a body will act as a buffer between the government and the collective bargaining process.

Table 3 lists the number and duration of strikes since the enactment of Bill 100. As noted above there have been a total of 54 sanctions (strikes and/or lockouts) and some of these have not been short lived. The longest sanction lasted a total of 56 school days. Strikes of this duration are considered extremely long even in the private sector. 
Table 2

Number of Sanctions (Strikes/Lockouts), Number of Advisements by the ERC, and Number of Occasions When Back-to-Work Legislation Has Been Enacted, Ontario Education, 1975-1989

$\begin{array}{cccc}\text { Year } & \text { Sanctions } & \text { Advisements } & \begin{array}{c}\text { Back-to-Work } \\ \text { Legislation }\end{array} \\ 1975-76 & 6 & 5 & 5 \\ 1976-77 & 3 & 0 & 0 \\ 1977-78 & 6 & 1 & 0 \\ 1978-79 & 3 & 0 & 0 \\ 1979-80 & 7 & 1 & 0 \\ 1980-81 & 4 & 0 & 0 \\ 1981-82 & 4 & 0 & 0 \\ 1982-83 & 1 & 0 & 0 \\ 1983-84 & 0 & 0 & 0 \\ 1984-85 & 5 & 0 & 0 \\ 1985-86 & 4 & 1 & 1 \\ 1986-87 & 6 & 0 & 0 \\ 1987-88 & 3 & 0 & 0 \\ 1988-89 & 2 & 0 & 0 \\ \text { Total } & 54 & 8 & 6\end{array}$

Source: Ontario, Education Relations Commission (Toronto).

As indicated in the table, on a number of occasions those who have headed the Education Relations Commission have tolerated strikes of twoand-a-half to three months before recommending to the cabinet that a teachers' strike should be ended. Given the high degree of public pressure in these types of disputes, it is unlikely that the government would have allowed strikes of that length if the ERC had not been in existence. The viability of the strike weapon, of course, is an issue of vital importance to the labour movement. It is central to the argument by Sack and Lee. The evidence in Ontario in this regard is clear and it is positive.

Under such an approach the Chairperson or Commissioner has many interventions from which to choose. I have noted this is true of the Commissioner under B.C. legislation and of the ERC Chairperson. The provisions are not identical but in broad outline there is a close resemblance. Conventional mediation, mediation teams, fact finding, supervised last offer votes, med-arb, mediation with recommendations, public hearings during a strike by the ERC, recommendations by the ERC to the cabinet on how to deal with sanctions, plus many other interventions are all part of the fourteen year collective bargaining experience under Bill 100 in Ontario. 
Table 3

Number and Length of Sanctions

(Instructional Days Lost Excluding Work-to-Rule),

Ontario Education, 1975-76 to 1988-89

\begin{tabular}{|c|c|c|c|c|}
\hline Year/School & Board & Number & Average Length & Longest Strike \\
\hline $1975-76$ & Secondary & 6 & 28,2 & 44 \\
\hline $1976-77$ & $\begin{array}{l}\text { Secondary } \\
\text { RCSS }\end{array}$ & $\begin{array}{l}2 \\
1\end{array}$ & $\begin{array}{r}12,0 \\
9,0\end{array}$ & $\begin{array}{r}24 \\
9\end{array}$ \\
\hline $1977-78$ & $\begin{array}{l}\text { Secondary } \\
\text { RCSS }\end{array}$ & $\begin{array}{l}5 \\
1\end{array}$ & $\begin{array}{l}26,7 \\
34,0\end{array}$ & $\begin{array}{l}44 \\
34\end{array}$ \\
\hline $1978-79$ & Secondary & 3 & 21,3 & 36 \\
\hline $1979-80$ & $\begin{array}{l}\text { Elementary } \\
\text { Secondary } \\
\text { RCSS }\end{array}$ & $\begin{array}{l}2 \\
3 \\
2\end{array}$ & $\begin{array}{l}17,5 \\
47,5 \\
16,0\end{array}$ & $\begin{array}{l}22 \\
56 \\
18\end{array}$ \\
\hline $1980-81$ & $\begin{array}{l}\text { Secondary } \\
\text { RCSS }\end{array}$ & $\begin{array}{l}3 \\
1\end{array}$ & $\begin{array}{r}38,3 \\
9,0\end{array}$ & $\begin{array}{r}47 \\
9\end{array}$ \\
\hline $1981-82$ & $\begin{array}{l}\text { Secondary } \\
\text { RCSS }\end{array}$ & $\begin{array}{l}2 \\
2\end{array}$ & $\begin{array}{l}25,5 \\
15,0\end{array}$ & $\begin{array}{l}51 \\
19\end{array}$ \\
\hline $1982-83$ & Secondary & 1 & 1,0 & 1 \\
\hline $1983-84$ & & 0 & 0,0 & 0 \\
\hline $1984-85$ & $\begin{array}{l}\text { Secondary } \\
\text { RCSS }\end{array}$ & $\begin{array}{l}2 \\
3\end{array}$ & $\begin{array}{l}29,5 \\
15,0\end{array}$ & $\begin{array}{l}30 \\
21\end{array}$ \\
\hline $1985-86$ & $\begin{array}{l}\text { Secondary } \\
\text { RCSS }\end{array}$ & $\begin{array}{l}3 \\
1\end{array}$ & $\begin{array}{r}33,3 \\
5,0\end{array}$ & $\begin{array}{r}50 \\
5\end{array}$ \\
\hline $1986-87$ & $\begin{array}{l}\text { Secondary } \\
\text { RCSS }\end{array}$ & $\begin{array}{l}1 \\
5\end{array}$ & $\begin{array}{l}33,0 \\
20,0\end{array}$ & $\begin{array}{l}33 \\
23\end{array}$ \\
\hline $1987-88$ & $\begin{array}{l}\text { Elementary } \\
\text { RCSS }\end{array}$ & $\begin{array}{l}1 \\
2\end{array}$ & $\begin{array}{r}18,0 \\
8,5\end{array}$ & $\begin{array}{l}18 \\
11\end{array}$ \\
\hline $1988-89$ & $\begin{array}{l}\text { Secondary } \\
\text { RCSS }\end{array}$ & $\begin{array}{r}1 \\
44\end{array}$ & $\begin{array}{r}1,0 \\
44,0\end{array}$ & $\begin{array}{r}1 \\
44\end{array}$ \\
\hline
\end{tabular}

Source: Ontario, Education Relations Commission (Toronto).

There is no question that, when necessary, with the above array of options at its disposal such an agency can bring a great deal of pressure to bear on both sides in a dispute. This helps rather than harms the collective bargaining process in strike and/or lockout situations. That is, the emphasis in Ontario education consistently has been on voluntary dispute resolution rather than on legislative solutions. This will be discussed further in the next section. 
At any rate, negotiations under Bill 100 in Ontario not only have been and continue to be in a healthy state but also the strike weapon remains a viable alternative to be utilized by unions if negotiations break down. Voluntary dispute resolution has been emphasized and third party intervention has been minimized. In short, the negotiation process closely mirrors the process in the private sector. This is precisely what the Canadian labour movement wants.

\section{ENCOURAGING VOLUNTARY DISPUTE RESOLUTION}

Sack and Lee, of course, are concerned with the B.C. legislation because it gives the Commissioner of the Industrial Relations Council sweeping powers to intervene in collective bargaining. This concern I believe is misplaced. There is a need in labour relations for dispute settlement mechanisms which are flexible and innovative in order to avoid back-towork legislation. This typically has not occurred in Canadian industrial relations because, I believe, this type of approach requires a specialized agency with a broad mandate in dispute resolution.

The experience with Bill 100 provides some confirmation in this regard. The statute allows and encourages different approaches and strategies in different situations. A major lesson to date is that no two strikes are the same, nor is the impact of the strike identical in each case. Therefore, each case has been treated differently by the Commission and an array of interventions has proven necessary.

Happily this is congruent with the approach called for by many experts in industrial relations. For the effective functioning of collective bargaining a dispute settlement agency must keep the parties guessing with respect to the type of intervention which might occur when sanctions do occur. If the approaches become predictable the parties will simply build these into their negotiating strategies. The variety of sanctions and their impact, noted above, present the opportunity to pursue such a policy. This is similar to the arsenal of weapons approach presented some years ago in the industrial relations literature (Chamberlain, 1958; Raskin, 1965; Shultz and Coleman, 1959).

An example will illustrate how the Commission has pursued the above policy to encourage voluntary dispute resolution by the parties rather than back-to-work legislation - a goal that Sack and Lee would endorse. As noted above, some lengthy sanctions have been tolerated but, as well, the Commission has made it clear that the students' courses must not be placed in jeopardy. The determination of when a sanction will jeopardized the students' courses of study is not only a difficult task but also one where there is immense pressure on the Commission to act - not only from politicians within the government but also in some cases from the opposition parties in the Legislature and from parents. The latter, if they are not satisfied with the Commission's actions, can file complaints with the provincial Ombudsman concerning those actions and the Commission will be (and has been) investigated. 
Against this background, a strike by the Leeds and Grenville secondary school teachers presented the Commission with a difficult but unique situation. That strike began in May 1981, after seventeen months of negotiations. By early June, the students had missed five weeks of school, and the state of negotiations was deteriorating. It was clear that the dispute would not be settled, if at all, until the summer holidays. For the first time the Commission was faced with the possibility of a total withdrawal of services which would span two school years. Parents and various politicians were extremely upset with the situation but, more importantly, there was absolutely no end in sight to the strike and the Legislature was about to adjourn for the summer. As a consequence, the Commission wrote to the Minister of Education on 11 June. This letter recommended that the Minister:

[...] consider the enactment of legislation before the adjournment of the Legislature to terminate the secondary school strike in Leeds and Grenville and that proclamation of the legislation by the Lieutenant Governor-in-Council be deferred until such time as an advisement under section $60(1)(h)$ is tendered by the Commission (italics added).

As a result, legislation to end the strike was enacted but not proclaimed. This allowed the Commission to offer some assurance to parents, students and the public that their concerns were being seriously considered. It also allowed the Commission to investigate in a more detailed fashion the matter of jeopardy but at the same time negotiations between the parties could continue. Moreover, on the recommendation of the Commission, the legislation contained terms which put pressure on both parties to settle the dispute on their own.

It did this by including the following features for resolving the dispute if the Act had to be proclaimed in the Fall: (1) all unresolved issues would go to final-offer-selection (total package) for resolution; (2) the choice of the selector would be by the Commission; (3) there would be a compulsory three-year collective agreement.

In July, the ERC notified the parties that it was calling for submissions from interested individuals and organizations in the community on the issue of jeopardy assuming the schools did not open in September. The Commission believed (as things turned out, correctly) that this could be done without the usual chilling effects on negotiation because the pressure placed on the parties to negotiate would be very considerable.

The legislation was never proclaimed. With the assistance of a mediator, the parties (faced with the imposition of FOS total package and a compulsory three-year collective agreement) settled on their own just prior to Labour Day and the schools opened on schedule.

\section{PRESERVING COLLECTIVE BARGAINING}

The ERC's predominant concern, then, has been to enhance the collective bargaining process. The experience in Ontario also suggests that, in 
other ways, a dispute settlement commission is more likely than a regular government department to go out of its way to preserve the collective bargaining system under its aegis. For example, Sack and Lee are critical of government wage restraint legislation as another example of unwarranted state intervention which has limited the union's right to collective bargaining. They state:

[...] in 1982, the federal government resorted to wage controls, this time applying them to the federal public sector only, even though federal government wage settlements in previous years had been moderate and consistent with settlements in the private sector [...]. Many, though not all, provincial governments likewise imposed wage controls on their public sector employees. As in 1975, the legislation suspended collective bargaining and the right to strike; however, the suspension of bargaining applied not only to wages, but to all non-monetary working conditions as well. In effect, the normal functions of trade unions were «put on ice» by the State for a twoyear period, surely unnecessary and arbitrary, since even during World War II, when wage controls were imposed, the right to strike over non-monetary matters was not suspended (p. 202).

The Ontario government introduced a virtual carbon copy (Bill 179) of the above mentioned federal wage restraint legislation. The Ontario Ministry of Labour rendered an immediate verdict that the legislation meant collective bargaining was suspended for the duration of the legislation. As a consequence, the Ministry refused to appoint third parties to collective bargaining disputes.

The Ontario Labour Relations Board faced a similar issue when Locals 204 and 210 of the Service Employees' Union applied for certification as bargaining agent at a nursing home known as Broadway Manor. At the time of the application, the employees were represented by The Christian Labour Association of Canada. The latter had signed a collective agreement which was to expire December 31, 1982. Ordinarily, the Board would have directed that a representation election be held among the employees of the bargaining unit. In this case it did so but ordered that the ballot boxes be sealed pending the Board's decision regarding the effect of the Inflation Restraint Act (IRA). The issue before the Board was whether the Act extended the collective agreement and thus rendered the application untimely. After a review of both sides of the issue the Board followed the interpretation of the IRA rendered by the Ministry of Labour. It held that the Act extended the collective agreement and thus made untimely the union's application for certification.

On the other hand, the Education Relations Commission which has both quasi-judicial and facilitative functions was faced with a similar situation to the Ministry and the Board. At the Durham County Board of Education the Ontario Secondary School Teachers' Federation brought a bad faith bargaining charge against the above mentioned employer. The issue arose when the employer took the position following the enactment of the Inflation Restraint Act that the effect of the legislation was to continue the collective agreement in force. Therefore, by this logic it had no legal obligation to bargain. 
By the time the Commission heard the case the Ministry and the OLRB had rendered decisions on the matter and the Commission was under considerable pressure to follow suit. Instead, the Commission (with one member dissenting) held that the Inflation Restraint Act did not suspend the Commission's jurisdiction (in this case to make a determination in a bad faith bargaining case). In essence the Commission was taking the position that the Inflation Restraint Act did not abrogate collective bargaining. According to the Commission, normal labour relations could continue subject to the regulation of compensation under IRA - a position irreconcilably contrary to the decision taken by the Ministry of Labour for public sector labour relations under its aegis'.

Both Broadway Manor and Durham were appealed to the Divisional Court of Ontario. The Court, in October 1983, upheld the decision of the Education Relations Commission. That decision, in turn, was appealed to the Court of Appeal. Again the decision of the Commission was upheld.

This was not the first nor the last time the Commission was to take a very independent stance. In one of its earliest decisions the Commission had to advise the government whether a teachers' strike in Windsor was placing in jeopardy the students' courses of study. If so, such an advisement would pave the way for back-to-work legislation. The review was held at the request of the government. Nevertheless, the Commission advised there was no jeopardy and, in face of that advisement, the government did not act and the strike continued.

There are at least two reasons why a dispute settlement agency is likely to operate in a more independent fashion. First, its credibility with the parties demands an independent stance and, secondly, it is not integrated into the government bureaucracy to the same degree as a Ministry or a department within a Ministry.

\section{MIXING QUASI-JUDICIAL AND FACILITATIVE FUNCTIONS}

A major criticisms of the B.C. legislation is that the Industrial Relations Council, the body Sack and Lee are predominately concerned with, has been given both an adjudicative and a facilitative function. Some have argued that it will be impossible to perform both functions and, at the same time, maintain the credibility and neutrality of these very different roles.

1 The ERC held that the effect of section 13 of the IRA was not to extend the life of the agreement itself but only to extend its terms and conditions and that therefore the notice of desire to negotiate was timely. The Commission stated: «We have concluded that, by extending the terms and conditions of the collective agreement, s. 13 of The Act does not prevent contract expiry from occurring nor does it result in a new collective agreement.) The OLRB held that the effect of section 13 of the Inflation Restraint Act (which extended the terms and conditions of the collective agreement) was to extend the life of collective agreements, and that therefore the application for certification was not made within the last two months of the operation of the collective agreement. Therefore, the application was untimely pursuant to Section 5(4) of the Ontario Labour Relations Act. 
Each role may impact on the other with some unfortunate side effects. It is felt that difficult decisions by the Council in one arena (e.g. intervening to end a strike) may negatively impact its credibility in the other.

It is worth noting, then, that the two functions are combined within the Education Relations Commission. Similarly, in a number of U.S. jurisdictions the two functions are included under one labour relations agency (Goldberg, 1972). The experience has not been a negative one (see for example Helsby and Joyner, 1972; Slavney and Bellman, 1972). It is possible to set up two separate administrative structures to compartmentalise the two functions but, more importantly, from a labour relations perspective there are advantages in mixing, at least to some extent, the two functions. For example, there is often a need for some co-ordination between them.

By placing both functions under the control of one individual, the Commissioner or Chairperson, who is familiar with and/or sensitive to the adjudicative and facilitative subtleties of policy, and of particular cases, coordination and sensible labour relations policy is more likely. For example, in a case where there is a strike, it may be helpful to mediation efforts to expedite a hearing by the adjudicative branch into a bad faith bargaining charge brought by one of the parties involved in the strike. Or, in a bad faith bargaining case it may be helpful to be aware of some of the collective bargaining nuances which come to ones attention in the facilitative function.

A case within the jurisdiction of the ERC is illustrative. In 1986 the Ontario government passed Bill 30 which extended full funding to Roman Catholic School Boards up to grade 13 rather than, as previously, to grade 10. The legislation did not specify the collective bargaining arrangements for the newly funded boards. The ERC realized there would be questions by existing teacher unions concerning collective bargaining representation and structure arising from the legislation. It, therefore, made private submissions to the government urging that the legislation include an amendment on collective bargaining structure. However, the legislation was not amended.

Once Bill 30 was enacted a union in the separate school system immediately sought to negotiate separate elementary and secondary collective agreements with a Roman Catholic School Board. The employer refused to do so, insisting instead on negotiating one collective agreement covering both elementary and secondary teachers. The union brought a charge before the Commission of failure to negotiate in good faith. In a unanimous decision, the Commission ruled for the union thus establishing a collective bargaining structure which is congruent with the public school system, cognizant of historical developments and in harmony with the institutional arrangements which have been an important part of the Ontario education system for many years ${ }^{2}$.

2 The employer appealed the Commission's decision but in November 1988 it was upheld by the Divisional Court. Also, following the decision by the ERC, new legislation covering French language schools in the province explicitly provided for separate elementary and secondary negotiations in those school systems. 


\section{BACK-TO-WORK LEGISLATION WITH A DIFFERENCE}

Notwithstanding the above, should the concept of a dispute settlement agency be applied to the public and private sectors? This is clearly a concern of Sack and Lee with respect to the B.C. approach.

Sack and Lee seem to believe that collective bargaining in the private sector should be free from government intervention. However, there may be cases in the private sector where a long strike or lockout could seriously damage or irreparably harm the interests of those who are not parties to the sanction. Or, there may be cases where an employer's intention is to break or weaken a union either by locking out or holding out an inordinate length of time when there is a strike. The recent strike at Eastern Air Lines in the U.S. and the Gainers strike in Canada are examples. There is a role for government intervention in such cases.

This type of proposition was included in a White Paper of the NDP government in Manitoba in 1984 although ensuing legislation enacted in 1985 excluded the idea (Black, 1985).

Under the White Paper proposal, both the employer and the union could request a vote taken of the members of the bargaining unit, including during a strike or lockout, to determine if employees would support the resolution of the dispute by FOS. A government-supervised vote would then be conducted. If the vote supported FOS, «[...] work stoppages [...] would not be allowed, or if in progress, could not continue». The parties would then appoint a selector, or, failing agreement between the parties, the Labour Board would designate a selector, who would choose either the employer offer or the union proposal as the basis of settlement (although the White Paper is not clear on whether this would be done on an issue by issue basis, or on the basis of the entire package) (p. 150).

According to Black, this provision would be of some advantage to unions which are embroiled in a lost strike.

In that situation, for example, when it became apparent that the strike was being lost [...] then a settlement would have been imposed, most workers would have retained their jobs and the union local would have survived. The 'hooker' in the arrangement, of course, is that an arbitrator might opt for the employer's position. Unions would have to weigh this risk against the risk of losing the strike and accepting the attendant consequences (pp. 150-151).

A dispute settlement tribunal when it has a broad mandate for dispute resolution can institute this type of policy. A variation of the approach was utilized by the Education Relations Commission in 1985.

In September, the secondary school teachers in Wellington County began a complete withdrawal of services. Prior to the sanction, negotiations were conducted for a period of 22 months. During the negotiations the Commission had appointed a fact finder and two mediators to assist the parties. The fact finder's report was comprehensive and included specific recommendations with respect to terms for settlement. The first mediator spent more than 140 hours with the parties during the period March 1985 to June 1985. 
A second mediator was appointed in June and spent more than 300 hours assisting the parties, 200 of which were spent after the sanction commenced in the Fall. At one point during mediation, the third party neutral, who at this point was very knowledgeable about the outstanding issues, presented to the parties a comprehensive «mediator's proposal» in an effort to resolve the dispute on a fair and reasonable basis. The union accepted all of the proposal. The employer totally rejected it.

When the strike was well into its third month the Commission advised the Lieutenant Governor-in-Council that, in the opinion of the Commission, the continuance of the strike would jeopardize the students' courses of study. The Minister of Education introduced Bill 63 which terminated the strike. On the advice of the Commission it included a provision which required the parties to execute a collective agreement containing all of the recommendations made by the mediator in the mediator's proposal mentioned above. In effect, the mediator's proposal became the collective agreement.

Needless to say, the employer was not happy with the above result. However, from all the Commission knew about the dispute and the issues outstanding, it was satisfied that the proposal was a fair resolution of the situation. It had also become obvious that the employer had no intention of negotiating or concluding a collective agreement. Rather the Board was simply waiting for and urging government intervention to end the sanction. The Commission's actions were intended as a warning to those parties who in the future might be tempted to follow a similar course. In short, if one of the parties were counting on back-to-work legislation to relieve them of their negotiating responsibilities, they might come to regret that action.

\section{PUBLIC POLICY TRADEOFFS}

To sum up, the ERC has tried to ensure the possibility of viable sanctions in an important public sector, minimize back-to-work legislation, minimize its own intervention in the more that 2,450 sets of negotiations conducted under the statute, and conduct its adjudicative and facilitative functions in a responsible fashion while taking into account institutional needs and historical circumstances. It has endeavoured its powers not only in an independent fashion but also in a way which assists the parties and protects the public interest.

Sack and Lee seem to have concluded that intervention in the collective bargaining process through a dispute settlement commission is, ipso facto, evidence of anti-unionism and an anti-collective bargaining animus. I have argued that this position misunderstands the positive role that such an agency can play in collective bargaining. As well, it does not take into account the tradeoffs involved in public policy.

In an article in Relations Industrielles a Canadian scholar has provided a useful framework to evaluate public policy toward collective bargaining and has noted the compromises which are entailed in policy formulation (Carrothers, 1985). He has argued that to have an effective process of collective bargaining, a legal system must protect employees in three areas - 
(1) the protected right of employees to form union; (2) the requirement to bargain in good faith; and, (3) the right to invoke meaningful sanctions against the employer.

These rights are not absolute, however. While there is an obligation on government not to interfere with the above freedoms, he argues that others have claims of their own which compete with and limit the above freedoms. He suggests, for example, that there are competing interests such as the employer's right to manage, and the individual employees right to work.

The list of competing rights, freedoms and interests does not stop there. The public, in the sense of collectivity of private citizens, has a claim to access to goods and services. The public, as the totality of its citizens, has an overriding claim that the government must govern. Collective bargaining is not an «extra-parliamentary process" (p. 360).

Because of competing rights Carrothers has commented that the provision of the right to invoke meaningful sanctions «is easy to state and enormously complicated in its execution» (p. 357). On occasion, there must be a tradeoff and intervention in the collective bargaining process will be necessary.

Moreover, these tradeoffs must be made in public and private sector bargaining. Some years ago a leading U.S. industrial relations scholar and practitioner in arguing that public sector employees should be given the right to strike stated:

I do not mean to suggest that [...] the right to strike is sacrosanct. On the contrary, it is a right like other rights that must be weighed against the larger public interest, and it must be subordinated where necessary to the superior right of the public to protection against injury [...]. These principles, in my judgment, apply to the private sector as well as the public sector. Moreover, their application cannot be determined in advance (Kheel, 1972, p. 263).

We in industrial relations have argued, after all, that there should not be rigid distinctions between private and public sector employees regarding collective bargaining and workplace rights. This is not to argue that public sector and private sector collective bargaining necessarily should be covered by the same legislation. For example, one well informed expert in industrial relations (Finkleman, 1986) believes public sector bargaining is distinctly different than private sector bargaining and that there should be different government bodies dealing with each type. But the coverage of the public and the private sectors by the same dispute resolution agency (as in British Columbia) should not be considered as anti-collective bargaining or, for that matter, anti-union. What is far more important is the substance of the legislation.

The issue in private sector bargaining is not whether or not the government will or will not play a role in dispute resolution. In Canada there is a long history of government intervention in private sector labour relations including collective bargaining. Rather, the issue is - how can our collective bargaining system be preserved and made to function more effectively? Those two issues are not mutually exclusive and they apply in the private and public sector. 
If the ERC model is to be applied in either sector, there are several essential ingredients for the preservation and efficacy of our system of collective bargaining. These are that intervention be minimized, the dispute resolution procedures be fair, the bargaining power of the parties be equally balanced in legislation and in execution, that the independence of a dispute settlement agency be assured, and that the legislation be administered in a fashion which ensures the right to undertake viable sanctions or, in rare cases were intervention is necessary (and the right-to-strike restricted), there be provision for equitable and speedy dispute resolution procedures.

\section{INNOVATION IN COLLECTIVE BARGAINING}

Because jurisdiction for labour relations is decentralized in Canada, there has been a variety of approaches within various jurisdictions and an opportunity for experimentation and innovation. This is often recognized as a strength of Canadian public policy (Craig, 1983, p. 240). A number of established systems are now in need of reform. To name just two, scholars have called for change in the Public Service Staff Relations Act (Finkleman, 1986; Subbarao, 1985; Swimmer and Winer, 1988) and the Ontario Hospital Labour Disputes Arbitration Act (Andiappan, Cattaneo and Murphy, 1984; Kruger, 1985). In these and other sectors we should be looking for new and improved approaches to industrial relations problems. Given the matrix of policy choices we face and the experience to date with the Education Relations Commission, new legislation to provide for specialized dispute settlement agencies makes a great deal of sense.

In this context, the B.C. approach to dispute resolution should be examined and evaluated with an open mind. The experience with a dispute resolution commission in that jurisdiction may be different than the experience in Ontario, and it may fail, but if so it will not be because of the dispute resolution provisions in the legislation. These in and of themselves present no threat either to unions or to collective bargaining. Indeed, they are arguably a creative response to industrial relations conflict.

In the latter regard, it is interesting to note that in bilateral trade, international and domestic law, and many other areas, various governments and interest groups are searching for and finding new and innovative ways to resolve disputes and manage conflict. It is ironic that in industrial relations, a field where the central focus has been of conflict resolution, some practitioners stand instead on old shibboleths.

\section{REFERENCES}

Andiappan, P., R. Cattaneo, J. Murphy, «Interest Arbitration in Ontario Hospitals: Result of an Attitude Survey of Union and Management Officials», Relations Industrielles, Québec, PUL, vol. 39, no 4, 1984, pp. 680-694. 
BLACK, E., «In Search of 'Industrial Harmony': The Process of Labour Law Reform in Manitoba, 1984», Relations Industrielles, Québec, PUL, vol, 40, no 1, 1985, pp. 140-160.

CARrothers, A., "A Way of Thinking About Collective Bargaining: Circumstance, Policy, Law and Actuality, Relations Industrielles, Québec, PUL, vol. 40, no 2, 1985, pp. 351-366.

Chamberlain, N., Labor, New York, McGraw-Hill Book Company, 1958.

Charles, L., E. HuMPhreys, «Bargaining to Achieve Teacher Control in Ontario», Relations Industrielles, Québec, PUL, vol. 40, no 3, 1985, pp. 495-509.

CRAIG, A., The System of Industrial Relations in Canada, Scarborough, Ontario, Prentice-Hall Canada, 1983.

DownIE, B., «Collective Bargaining Under an Essential Services Disputes Commission", in M. Thompson, G. Swimmer (Ed.), Conflict or Compromise: The Future of Public Sector Industrial Relations, Montréal, Québec, The Institute for Research on Public Policy, 1984, pp. 373-401.

Finkleman, J., «Public Sector Collective Bargaining», Relations Industrielles, Québec, PUL, vol. 41, no 4, 1986, pp. 691-702.

Goldberg, J., «Labor-Management Relations Laws in Public Service», in J. Loewenberg, M. Moskow (Ed.), Collective Bargaining in Government, Englewood Cliffs, N.J., Prentice-Hall, 1972, pp. 26-46.

HELSBY, R. and T. JOYNER, «A Separate Agency For Administering Collective Bargaining By Public Employees», in J. Loewenberg and M. Moskow (Ed.), Collective Bargaining in Government, Englewood Cliff, N.J., Prentice-Hall, 1972, pp. 100-107.

JACKSON, R., Fact Finding under the Ontario School Boards and Teachers Collective Negotiations Act, Toronto, Ontario Education Relations Commission, 1989.

KHEEL, T., «Resolving Deadlocks Without Banning Strikes», in J. Loewenberg and M. Moskow (Ed.), Collective Bargaining in Government, Englewood Cliff, N.J., Prentice-Hall, 1972, pp. 262-264.

Kruger, A., «Collective Bargaining in Ontario Public Hospitals», Relations Industrielles, Québec, PUL, vol. 40, no 1, 1985, pp. 48-67.

Ontario Education Relations Commission, Annual Report 1986-87, Toronto, Ontario, 1987.

RASKIN, A., «The Government's Role When Bargaining Breaks Down», in R. Lester (Ed.), Labor: Readings on Major Issues, New York, Random House, 1965, pp. 471-481.

SACK, J., T. LEE, «The Role of the State in Canadian Labour Relations», Relations Industrielles, Québec, PUL, vol. 44, no 1, 1989, pp. 195-221.

Shultz, G., J. Coleman, Labor Problems: Cases and Readings, New York, McGraw-Hill Book Company, 1959.

Slavney, M., H. Bellman, «A Common Agency for Administering Collective Bargaining by Public and Private Employees, in J. Loewenberg, M. Moskow (Ed.), Collective Bargaining in Government, Englewood Cliff, N.J., Prentice-Hall, 1972, pp. 94-100.

SubBarao, A., «Impasse Choice in the Canadian Federal Service: An Innovation and an Intrigue», Relations Industrielles, Québec, PUL, vol. 40, no 3, 1985, pp. 567-590. 
SwIMMER, G., S. WINER, «Dispute Resolution and Self-Selection in the Public Service», Les relations industrielles, une perspective internationale/Some Aspects of International Industrial Relations, Proceedings of the $25^{\text {th }}$ Meeting of the Canadian Industrial Relations Association, Université Laval, Québec City, Canada, 1988, pp. 189-200.

Woods, H.D., A.W.R. CARrothers, J.H.G. CrisPo, G. Dion, Canadian Industrial Relations: The Report of the Task Force on Labour Relations, Ottawa, Privy Council Office, 1968.

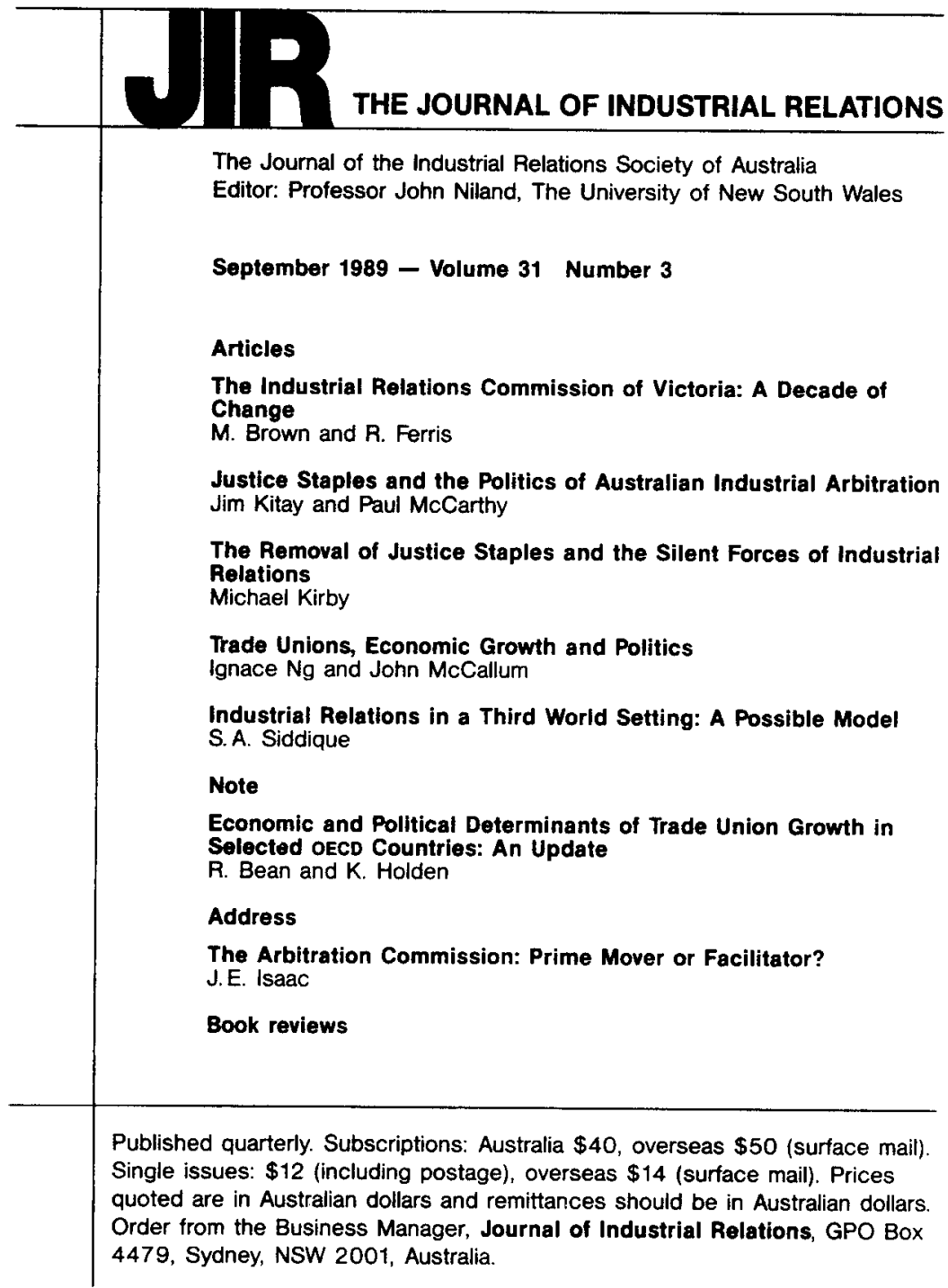

